\title{
Assessment of Knowledge and Attitude of Medical Students Regarding Body and Organ Donation
}

\author{
Mrinal Kanti Ray ${ }^{1}$ and Tapas Ghosh ${ }^{2 *}$ \\ ${ }^{1}$ Associate professor, Orthopedics Department, Burdwan Medical College and Hospital, Burdwan, West Bengal,India. \\ ${ }^{2}$ Associate Professor, Anatomy Department, Burdwan Medical College, Burdwan, West Bengal, India
}

\begin{abstract}
DOI: $10.36348 /$ sjm.2020.v05i01.004
| Received: 01.01.2020 | Accepted: 08.01.2020 | Published: 15.01.2020
\end{abstract}

*Corresponding author: Tapas Ghosh

Abstract

Background: The number of kidney, liver, heart and other organ transplants is growing rapidly, but not nearly as rapidly as the growth in the number of persons with defective organs who desire transplants. Also, cadavers are needed for Anatomy dissection classes for medical students. Methods: The study assessed the knowledge and awareness levels of 134 first professional MBBS students, who filled a prevalidated questionnaire. Observations and Results: Out of 134 students, $87.3 \%$ of the respondents were aware of the concept of organ donation while $12.7 \%$ had not even heard about it. $83.7 \%, 78.6 \%, 36.8 \%$ and $20.5 \%$ were aware about eye, kidney, whole body and liver donations respectively. Awareness of donation of other organs was found to be in the range between $11.9 \%$ and $7.7 \% .48 .7 \%, 29.1 \%, 14.2 \%, 9.4 \%$ and $1 \%$ of the aware respondents started that television, internet, newspaper, family members and other sources respectively were their sources of information regarding organ donation. Conclusions: Educating the public, supportive care, proper infrastructure, addressing various issues of organ and body donation - all these can help in improving the peoples' understanding, and therefore increased rate of donation.

Keywords: Organ, body donation, medical students, awareness.

Copyright @ 2020: This is an open-access article distributed under the terms of the Creative Commons Attribution license which permits unrestricted use, distribution, and reproduction in any medium for non-commercial use (NonCommercial, or CC-BY-NC) provided the original author and source are credited.

\section{INTRODUCTION}

The number of kidney, liver, heart and other organ transplants is growing rapidly, but not nearly as rapidly as the growth in the number of persons with defective organs who desire transplants [1]. However, organs procured by organ donation have to be available for such transplantation surgeries to take place. The benefits of getting immediate access to a transplant are significant because longer waiting times on dialysis negatively impact the success rate of transplantation and patient survival for example, long-term mortality rates are between 50 to 80 percent lower among transplant recipients than among patients on the waiting list $[2,3]$. But on the other hand, dialysis and transplantation costs consume sizeable proportions of health budgets [4]. Obviously, affluent patients in nations with long waiting lists do not always wait for donations from within their own countries. Commercially driven transplantation, however, does not always ensure proper medical care of recipients or donors, and might lengthen waiting times for resident patients or increase the illegal and unethical purchase of organs from living donors [5]. Developments in organ preservation and retrieval, in surgical and anesthetic management and postoperative care, immunosuppression, and tolerance have all contributed not only to better outcomes but to making transplantation more accessible as surgeons accept older and higher risk recipients and as more contraindications (such as infection with hepatitis B virus or HIV) have been removed. These events, all welcome, have combined to make the donor pool smaller and higher risk and the number of people who would benefit from transplantation greater [6].

Thus, body and organ donation in significant numbers is needed to meet the present demand for transplantation. In addition, body donation is required for medical students for dissection in Anatomy classes. In the present study, we tried to assess the knowledge and attitude of certain populations like medical students with respect to organ and body donation.

\section{EXPERIMENTAL SECTION}

This cross sectional study was conducted in the department of Anatomy of a tertiary care medical college. The study assessed the knowledge and awareness levels of first professional MBBS students of medical college. The study period was May 2018 to 
April 2019. A sample questionnaire was prepared by the research team. The questionnaire was first pre validated by 5 professors and faculties of the college who acted as a team of expert having sound knowledge related to organ donation. Students studying in first professional MBBS were included. The students whose permanent place of residence was outside West Bengal were excluded. These questionnaires were provided to 134 randomly selected first and second year MBBS students. They were given an hour to complete the test. After the filled questionnaire was collected, a discussion was carried out with the respondents about the need for organ donation in India. Information sheets were handed to all and the willing respondents were given eye and body donation forms and donor cards.

The data was compiled, analyzed and tabulated using SPSS Version 11.5.

\section{RESULTS} respondents.

Table-1: Demographic details of responders $(n=134)$.

\begin{tabular}{|l|l|l|l|}
\hline Demographic details of responders & Frequency & Percentage (\%) \\
\hline \multirow{3}{*}{ Gender } & Male: & 96 & 71.6 \\
\cline { 2 - 4 } & Female: & 38 & 28.4 \\
\hline \multirow{3}{*}{ Religion } & Hindu: & 115 & 85.8 \\
\cline { 2 - 4 } & Muslim: & 15 & 11.1 \\
\cline { 2 - 4 } & Christian: & 4 & 2.9 \\
\hline \multirow{2}{*}{ Background } & Urban: & 72 & 53.7 \\
\cline { 2 - 4 } & Rural: & 62 & 46.3 \\
\hline
\end{tabular}

Table-1 shows the detailed demography of the respondents. Of the total 134 respondents: $71.6 \%$ were male and $28.4 \%$ were female; $85.8 \%$ were Hindu,
$11.1 \%$ were Muslim and $2.9 \%$ were Christian; $53.7 \%$ were from urban and $46.3 \%$ from rural background.

Table-2: Sources of respondents for acquiring knowledge related to organ donation

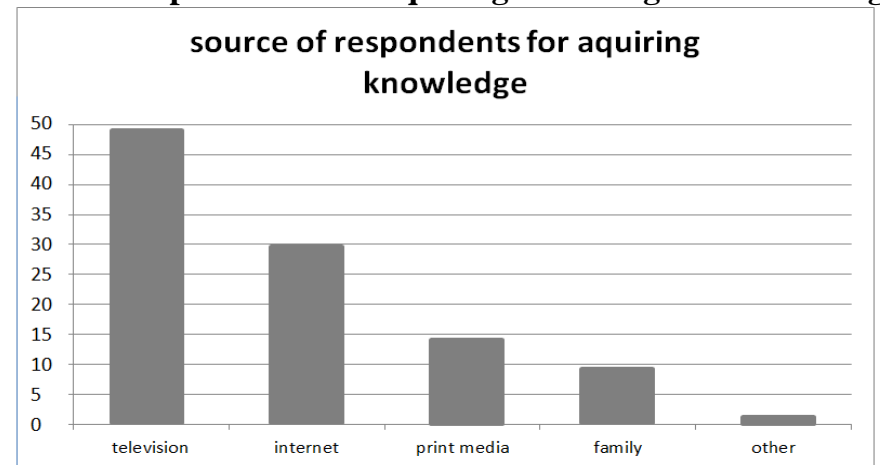

N.B. Many respondents claimed more than one source of information

Table-2 shows the different sources of respondents from which they acquired knowledge related to organ donation. $48.7 \%, 29.1 \%, 14.2 \%, 9.4 \%$ and $1 \%$ of the aware respondents started that television, internet, newspaper, family members and other sources respectively were their sources of information regarding organ donation.

Table-3: Opinions of respondents disgreeing to donate organs 


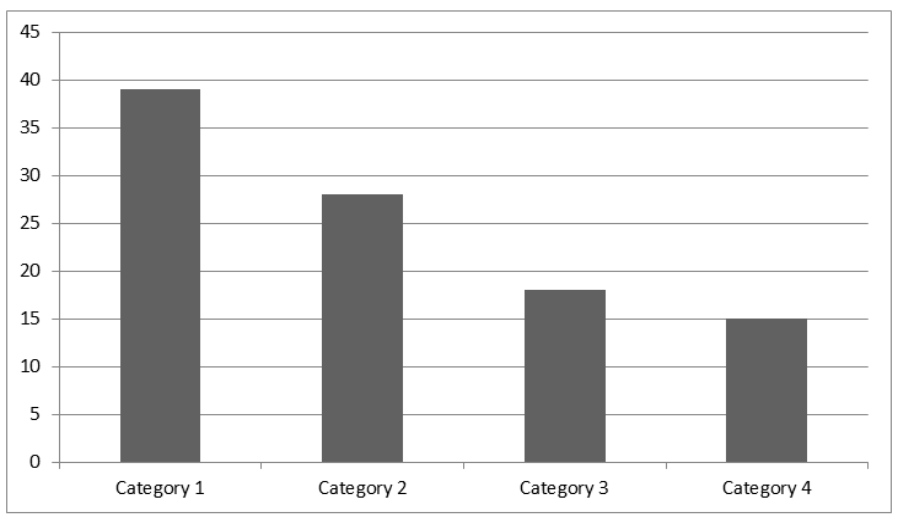

Table-3 shows the various responses when asked the reason for not donating their own organs: Category 1(40\%) - unawareness, Category 2(28.9\%)religious reasons, Category 3(17.8\%)-superstition, Category $4(13.3 \%)$ - fear that mutilation can impair burial rites.

Out of 134 students, $87.3 \%$ of the respondents were aware of the concept of organ donation while $12.7 \%$ had not even heard about it. $83.7 \%, 78.6 \%$, $36.8 \%$ and $20.5 \%$ were aware about eye, kidney, whole body and liver donations respectively. Awareness of donation of other organs was found to be in the range between $11.9 \%$ and $7.7 \%$. The detailed demography of the respondents is presented in Table-1, which shows that of the total 134 respondents: $78.6 \%$ were male and $28.4 \%$ were female; $85.8 \%$ were Hindu, $11.1 \%$ were Muslim and $2.9 \%$ were Christian; $53.7 \%$ were from urban and $46.3 \%$ from rural background. In Table-2 the various sources of respondents from which they acquired knowledge related to organ donation is shown; $48.7 \%, 29.1 \%, 14.2 \%, 9.4 \%$ and $1 \%$ of the aware respondents started that television, internet, newspaper, family members and other sources respectively were their sources of information regarding organ donation. Many respondents stated that they acquired knowledge from more than one source. When asked whether they would donate their own organs, 37.3\% stated 'yes', $29.1 \%$ were undecided, and $33.6 \%$ stated 'no'; of this $33.6 \%$, Table-3 shows the various responses when asked why they would not donate their own organs: $40 \%$ - unawareness, $28.9 \%$ - religious reasons, $17.8 \%$ superstition, $13.3 \%$ - fear that mutilation can impair burial rites.

\section{DISCUSSION}

While the public is supportive of organ transplantation, it is not overly enthusiastic about organ donation [7]. Improving the consent rate for organ donation from deceased donors should be a key component of strategies to increase the availability of organs for transplantation [8].

In our study, when asked if they knew the proper procedure for organ or body donation, a dismal $9 \%$ responded in the affirmative. Even worse was the percentage $(3.7 \%)$ of students who knew the existence

of a donor registry where one can register oneself for organ donation. On the other hand, 38\% knew about laws that only related living donors could donate organs for transplantation.

Out of 134 students, $87.3 \%$ of the respondents were aware of the concept of organ donation while $12.7 \%$ had not even heard about it. $83.7 \%, 78.6 \%$, $36.8 \%$ and $20.5 \%$ were aware about eye, kidney, whole body and liver donations respectively. Awareness of donation of other organs was found to be in the range between $11.9 \%$ and $7.7 \%$. The detailed demography of the respondents is presented in Table 1, which shows that of the total 134 respondents: $78.6 \%$ were male and $28.4 \%$ were female; $85.8 \%$ were Hindu, $11.1 \%$ were Muslim and $2.9 \%$ were Christian; $53.7 \%$ were from urban and $46.3 \%$ from rural background. In Table 2 the various sources of respondents from which they acquired knowledge related to organ donation is shown; $48.7 \%, 29.1 \%, 14.2 \%, 9.4 \%$ and $1 \%$ of the aware respondents started that television, internet, newspaper, family members and other sources respectively were their sources of information regarding organ donation. Many respondents stated that they acquired knowledge from more than one source. When asked whether they would donate their own organs, 37.3\% stated 'yes', $29.1 \%$ were undecided, and $33.6 \%$ stated 'no'; of this $33.6 \%$, table 3 shows the various responses when asked why they would not donate their own organs: $40 \%$ unawareness, $28.9 \%$ - religious reasons, $17.8 \%$ superstition, $13.3 \%$ - fear that mutilation can impair burial rites. The present study might give an approximate idea about the medical students' knowledge and attitude about donation.

Results of other studies of individuals who were asked to donate family members' organs suggested that the timing and privacy of the request, the involvement procurement staff and improved understanding of the meaning of brain death are key explanatory factors [9]. Recent studies suggest that, apart from cultural, social and educational issues and language barriers, religious concerns may also play a role in a decision against donation [10]. Knowledge of various facts may provide a background to deal with these issues professionally and appropriately and to increase transplant numbers [11]. 
Supportive emotional care for the family and reassurance and information about the donation process are indicated as important issues to address to encourage donation [12].

In addition, it is thought that proper laws can help in the above mentioned issues [13]. The legislation called the Transplantation of Human Organ Act (THO) was passed in India in 1994 to streamline organ donation and transplantation activities. Broadly, the act accepted brain death as a form of death and made the sale of organs a punishable offence. With the acceptance of brain death, it became possible to not only undertake kidney transplantations but also start other solid organ transplants like liver, heart, lungs, and pancreas. Despite the THO legislation, organ commerce and kidney scandals are regularly reported in the Indian media. In most instances, the implementation of the law has been flawed and more often than once its provisions have been abused [14]. Cantarovitch suggests that organ transplantation depends on a social contract and social trust and it requires national and international law protecting the rights of both organ donors and organ recipients [15].

\section{CONCLUSION}

Professionals, media and other resource personnel should be urged to increase awareness of organ and body donation among people. Educating the public, supportive care, proper infrastructure, addressing various issues of organ and body donation all these can help in improving the peoples' understanding, and therefore increased rate of donation.

\section{ACKNOWLEDGEMENTS}

Dr. Suhrita Paul, Professor, Pharmacology department, Principal, Burdwan Medical College

Dr. Jonaki Das Sarkar, Professor, Anatomy department, Burdwan Medical College

Dr. Goutam Chakraborti, Professor, Biochemistry department, Burdwan Medical College

Dr. Shyamalendu Medda, Assistant Professor, Physiology department, Burdwan Medical College

Dr. Debasish Biswas, Demonstrator, Anatomy department, Burdwan Medical College

\section{Funding: None}

Conflict of interest: None declared.

\section{REFERENCES}

1. Becker, G. S., \& Elias, J. J. (2007). Introducing incentives in the market for live and cadaveric organ donations. Journal of economic perspectives, 21(3), 3-24.

2. Wolfe, R. A., Ashby, V. B., Milford, E. L., Ojo, A. O., Ettenger, R. E., Agodoa, L. Y., ... \& Port, F. K. (1999). Comparison of mortality in all patients on dialysis, patients on dialysis awaiting transplantation, and recipients of a first cadaveric transplant. New England Journal of Medicine, 341(23), 1725-1730.

3. Edwards, E. B., Bennett, L. E., \& Cecka, J. M. (1997). Effect of HLA matching on the relative risk of mortality for kidney recipients: a comparison of the mortality risk after transplant to the mortality risk of remaining on the waiting list. Transplantation, 64(9), 1274-1277.

4. Howard, K., Salkeld, G., White, S., Mcdonald, S., Chadban, S., Craig, J. C., \& Cass, A. (2009). The cost- effectiveness of increasing kidney transplantation and home- based dialysis. Nephrology, 14(1), 123-132.

5. Delmonico, F. L., Domínguez-Gil, B., Matesanz, R., \& Noel, L. (2011). A call for government accountability to achieve national self-sufficiency in organ donation and transplantation. The Lancet, 378(9800), 1414-1418.

6. Johnson, R. J., Bradbury, L. L., Martin, K., \& Neuberger, J. (2014). Organ donation and transplantation in the UK - the last decade: a report from the UK national transplant registry. Transplantation, 97, S1-S27.

7. Manninen, D. L., \& Evans, R. W. (1985). Public attitudes and behavior regarding organ donation. Jama, 253(21), 3111-3115.

8. Vincent, A., \& Logan, L. (2012). Consent for organ donation. British journal of anaesthesia, 108(suppl_1), i80-i87.

9. DeJong, W., Franz, H. G., Wolfe, S. M., \& Howard, N. (1998). Requesting organ donation: an interview study of donor and nondonor families. American Journal of Critical Care, 7(1), 13-23.

10. Alkhawari, F. S., Stimson, G. V., \& Warrens, A. N. (2005). Attitudes toward transplantation in UK Muslim Indo- Asians in west London. American Journal of Transplantation, 5(6), 1326-1331.

11. Oliver, M., Woywodt, A., Ahmed, A., \& Saif, I. (2010). Organ donation, transplantation and religion. 26(2):437-444.

12. Siminoff, L., Mercer, M. B., Graham, G., \& Burant, C. (2007). The reasons families donate organs for transplantation: implications for policy and practice. Journal of Trauma and Acute Care Surgery, 62(4), 969-978.

13. Lavee, J., Ashkenazi, T., Stoler, A., Cohen, J., \& Beyar, R. (2013). Preliminary marked increase in the national organ donation rate in Israel following implementation of a new organ transplantation law. American Journal of Transplantation, 13(3), 780-785.

14. Shroff, S. (2009). Legal and ethical aspects of organ donation and transplantation. Indian journal of urology: IJU: journal of the Urological Society of India, 25(3), 348-355.

15. Delmonico, F. L., Arnold, R. M., Scheper-Hughes, N., Siminoff, L. A., Kahn, J., \& Younger, S. J. (2002). Organ donation by ethical incentives-not by sales. $N$ Engl J Med, 346, 2002-2005. 
